\title{
Recent hydrological response of glaciers in the Canadian Rockies to changing climate and glacier configuration
}

\author{
Dhiraj Pradhananga ${ }^{1,2,3}$, John W. Pomeroy ${ }^{1}$ \\ ${ }^{1}$ Centre for Hydrology, University of Saskatchewan, Canmore, 1151 Sidney Street, Alberta, Canada T1W 3G1 \\ ${ }^{2}$ Department of Meteorology, Tri-Chandra Multiple Campus, Tribhuvan University, Kathmandu, Nepal \\ ${ }^{3}$ The Small Earth Nepal, P.O. Box 20533, Kathmandu, Nepal
}

Correspondence to: Dhiraj Pradhananga (dhiraj.pradhananga@usask.ca)

\begin{abstract}
Mountain snow and ice greatly influence the hydrological cycle of alpine regions by regulating both the quantity and seasonal variations of water availability downstream. This study considers the combined impacts of climate and glaciers changes due to recession on the hydrology and water balance of two high-elevation basins in the Canadian Rockies. A distributed, physically based, uncalibrated glacier hydrology model developed in the Cold Regions Hydrological Modelling platform (CRHM) was used to simulate the glacier mass balance and basin hydrology of Peyto and Athabasca Glacier basins in Alberta. Bias-corrected reanalysis data were used to drive the model. The model calculates the water balance of a glacierized basin, influenced by the surface energy and mass balance, and considering redistribution of snow by wind and avalanches. It was set up using hydrological response units based on elevation bands, surface slope and aspect, as well as changing land cover. Aerial photos, satellite images and Digital Elevation Models (DEM) were assimilated to represent the changing configurations of glacier area and the exposure of ice and firn. Observations of glacier mass balance, snow and glacier ice surface elevation changes at glacier and alpine tundra meteorological stations and streamflow discharge at the glacier outlets were used to evaluate the model performance. Model results indicated that both basins have undergone continuous glacier loss over the last three to five decades, leading to a 6-31\% reduction in glacierized area, a 78-109\% increase in ice exposure, and changes to the elevation and slope of the glacier surfaces. Diurnal temperature ranges are increasing, mainly due to increasing summer maximum daily temperatures. Annual precipitation is not changing much, but rainfall ratios are increasing. Basin hydrology was simulated over two periods, 1965-1975 and 2008-2018, using observed glacier configurations. The results show that changes in both climate and glacier configuration caused changes in melt rates and runoff, and a shift of peak flows from August to July. Glacier melt contributions increased from 27-61\% to 43$59 \%$ of annual discharges. Recent discharges were 3-19\% higher than in the 1960s and 1970s. The results suggest that increased exposure of glacier ice and lower surface elevation due to glacier thinning were less influential in increasing streamflow than climate warming. Streamflow from these glaciers continues to increase.
\end{abstract}




\section{Introduction}

Mountain streamflow profoundly affects the quantity, quality and seasonal variation of downstream water availability, particularly in arid and semiarid regions of western North America (Marks et al., 2008). Glaciers contribute significantly to streamflow during warm and dry periods and in doing so moderate inter-annual variability and to flow water during extreme warm and dry periods (Comeau et al., 2009; Fountain and Tangborn, 1985; Hopkinson and Young, 1998). North American mountain glaciers, however, are retreating (Arendt et al., 2002; Comeau et al., 2009; DeBeer and Sharp, 2007; Demuth and Keller, 2006; Demuth and Pietroniro, 2003; Moore and Demuth, 2001; Munro, 2000; Reynolds and Young, 1997; Schiefer et al., 2007; Tennant and Menounos, 2013). The rate of glacier retreat is comparatively higher in recent decades than in the past, even though many glaciers began to retreat after the Little Ice Age ended in the early 1800s (Barry, 2006; Riedel et al., 2015).

Canada is experiencing a warming climate, with increased precipitation and greater spatial and seasonal variability (Derksen et al., 2012; Vincent et al., 2015). Derksen et al. (2012) reported increasing surface temperatures over the Canadian Arctic over the last four decades, increasing mass loss from glaciers, and a reduction in snow cover extent and duration. Vincent et al. (2015) reported increasing temperature and precipitation trends in Canada, with the greatest warming in winter and spring and more spatial variability in precipitation trends than in temperature trends.

There are some uncertainties with the hydrological response to glacial change. It is generally accepted that flow originating from glaciers will increase for a certain time due to increased melt rate, then decline when the mass of ice in the landscape decreases significantly (Moore et al., 2009). The duration and timing of this change from increasing to decreasing flow, however, will be regionally dependent (Casassa et al., 2009). In addition, recent studies have projected a different future for streamflow in the Himalayas than Moore et al. (2009) postulated. For example, Immerzeel et al. (2013) predicted a warmer and wetter future for the Himalayas. They argued that increasing precipitation in the region would compensate for declining contributions of glacier melt to river flow in the future. Luo et al. (2013) indicated that glacier melt was less sensitive to precipitation change than to temperature change in northwest China and suggested further modelling of the effects of climate change with both increasing temperatures and decreasing precipitation.

Stahl and Moore (2006) observed that British Columbia streams originating from glacierized mountain basins have shown a decreasing phase (in late summer flow) and indicated that most glaciers had already completed the phase of increased flow due to global warming. Kienzle et al. (2012) projected decreased summer and fall streamflow, exacerbated by reduced glacier flows, in Alberta's Cline River basin in western Canada. They observed earlier snowmelt, lower summer flow, an extended low-flow late summer period and greater autumn precipitation. The observed decrease in glacier mass in the Canadian Rockies has been caused by an increase in average annual air temperatures and a reduction in winter snowfall since the mid-1980s (Demuth and Keller, 2006, Moore and Demuth, 2001). 
Demuth and Keller (2006) conducted a detailed assessment of the mass balance variation of Peyto Glacier in Alberta from 1966-1995 and its change due to regional climate variability and climate change. They found that winter snow accumulation was a dominating factor for annual net mass balance. They attempted to establish the mass balance trend with shifts in synoptic climate variation, considering sea surface temperature, atmospheric circulation, seasonal snow and perennial ice. The Pacific Decadal Oscillation (PDO) and the El Nino Southern Oscillation (ENSO) were found to correlate with the winter mass balance. The study showed there has been a loss of $\sim 70 \%$ of glacier volume during the last century. Marshall et al. (2011) projected glacier volumes of the Canadian Rockies (eastern slopes) for the next century. Their projected values are alarming, as they indicate a further $\sim 85 \%$ loss of glacier volume by 2100 and an order of magnitude decrease in glacier contribution to streamflow in Alberta from $1.1 \mathrm{~km}^{3}$ per year at present to 0.1 $\mathrm{km}^{3}$ per year at the end of this century. Similarly, Clarke et al. (2015) projected the loss of the glaciers in western Canada by about $75 \%$ at the end of the $21^{\text {st }}$ Century compared to the glacier mass in 2005 .

Therefore, there are changes in both climate and glacier configuration with glacier retreat. However, it is yet to be fully understood how a glacier behaves with changing precipitation and temperature, along with changes in glacier configuration. Continuous glacier mass loss leads to a reduction in glacier-covered area, an increase in ice exposure and changes to the elevation and slope of the glacier surface. These changes alter the near-surface distribution of temperature and precipitation, as well as radiation and turbulent transfer of mass and energy to snow, firn and ice. This study investigates the individual and combined impacts of the changing climate and receding glaciers on headwater hydrology in two well studied glacierized basins on the eastern slopes of the Canadian Rockies.

\section{Methodology and data}

To diagnose the impacts of climate change and changing glacier configurations on mountain headwater hydrology, experiments were conducted by applying CRHM-glacier, a glacio-hydrological model. This was done in two research basins (AGRB and PGRB) in the Canadian Rockies considering climate of two periods (1965-1975 and 2008-2018) and glacier configurations of two periods, past (1966 for PGRB and 1981 for AGRB) and present (2011 for AGRB and 2014 for PGRB).

\subsection{CRHM-glacier model development}

The CRHM-glacier model (Pradhananga and Pomeroy, 2021), developed in the Cold Regions Hydrological Modelling Platform (Pomeroy et al., 2007) was applied in this study to evaluate the impacts of changes in climate and in glacier configuration on the hydrology of glacierized basins. CRHM-glacier is a physically based, flexible, multi-physics hydrological model (Pradhananga and Pomeroy, 2021). It distributes meteorological variables (shortwave and longwave radiation, air temperature, relative humidity, wind speed, precipitation and its phase) to slope, aspect and elevation within hydrological response units (HRU). CRHM-glacier simulates the hydrology of both glacier and nonglacier areas in a basin. It redistributes snow by coupling the blowing snow transport and sublimation process and avalanching. Melt energies for snow and ice melt are calculated separately, based on Snobal and energy budget glacier melt modules, respectively (Pradhananga and Pomeroy, 2021). Meltwater routing is through three glacier reservoirs 
(snow, firn, and ice) modified to the de Woul et al. (2006) approach. Once water leaves the glacier, rain and meltwater are routed further into the soil surface, subsurface and groundwater using well developed alpine routing routines (Fang et al., 2013).

The CRHM-glacier model was validated in two basins in western Canada - Peyto Glacier Research Basin (PGRB) in Banff National Park and Athabasca Glacier Research Basin (AGRB) in Jasper National Park (Pradhananga and Pomeroy, 2021). Previous research has successfully applied CRHM over several mountain sites (Krogh et al., 2015; Pomeroy et al., 2015; Rasouli et al., 2014; Zhou et al., 2014) and glacierized basins (Anderson, 2017).

\subsection{Study sites}

Two alpine glacier basins in the Canadian Rockies, PGRB and AGRB (Figure 1), were chosen for this research. The details of these basins were provided by Pradhananga and Pomeroy (submitted), a summary of which are in Table 1. Both glaciers have continuously been losing mass since the mid-1970s (Demuth and Keller, 2006; Kehrl et al., 2014; Reynolds and Young, 1997; Tennant and Menounos, 2013). Clarke et al. (2015) projected that AGRB will lose half its glacier coverage by 2050. Kehrl et al. (2014) estimated that Peyto Glacier may lose about $85 \%$ of its present-day mass by 2100 . Both glaciers are gauged at the outlets of their pro-glacier lakes.

\subsection{Modelling approaches (scenarios)}

CRHM-glacier was run to simulate the hydrological responses of the two glacier research basins to four experimental scenarios (Table 2 and Figure 2). The glacier configuration in each basin was considered for two periods, past and present. The model was run for two climate periods, past (1965-1975) and present (2008-2018). A novel approach was used - past and present climate forced both past and present glacier configurations. Therefore, there was a combination of four model simulations using two separate decades of climate data from past and present periods, with past and present glacier configurations. Simulated runoff from these model outputs was examined to diagnose the hydrological response to both glacier change and climate change.

Glacier configuration maps for the two periods were prepared according to the availability of DEM and landcover information (Table 2). A topographic map of Peyto Glacier from 1966 (Sedgwick and Henoch, 1975) was used to prepare a past glacier configuration. Both the 1966 DEM (10 m resolution) and the 1966 landcover map were developed from the topographic map, which was produced from aerial photographs taken in August 1966. The 2014 DEM was prepared at $10 \mathrm{~m}$ resolution from airborne Lidar measurements taken during July and September 2014. The landcover map for the present basin was prepared based upon a Landsat image from 2014. Bolch et al. (2010) found only $1.7 \%$ deviation in these two approaches (aerial photo and satellite images) for Peyto Glacier from the same year 2005 .

For AGRB, two DEMs, each at 20 m horizontal resolution, from 1983 and 2011, were used. Landsat images from 
Based on these four experimental scenarios, five comparison schemes (Table 3) were employed to diagnose the impacts of climate and glacier changes on streamflow. S1 represents realistic conditions of both climate and glacier configuration; it compares model scenarios A and D, i.e., past climate - past glacier with present climate - present glacier. The other schemes are falsified modeling experiments to segregate the impacts of changing climate and glacier configuration. S2 and S5 scenarios consider change in glacier configuration, while keeping climate the same, either past or present. S3 and S4 schemes compare the impacts from changing climate while keeping glacier configuration constant, either past or present glacier.

Student's t-test and the Wilcoxon Signed-Rank test in the R environment (R Core Team, 2017) were applied to test the significance of the changes between model scenarios. All tests were conducted at the 0.05 level of significance.

\subsection{Meteorological forcing datasets}

Bias-corrected ERA-40 (Uppala et al., 2005) and ERA-Interim reanalysis data (Dee et al., 2011) were used to force the model. These ERA global reanalysis were first bias corrected to in situ observational datasets at the single points near to the glaciers (Athabasca Moraine Station for AGRB and Peyto Main Station for PGRB, Figure 7). The meteorological variables that were used to run the CRHM-glacier were air temperature, vapour pressure, wind speed, precipitation, incoming short- and longwave radiation. In the second stage, these data were distributed to the basin HRUs using in-built algorithms and macros in CRHM (Pomeroy et al., 2007). The HRUs of these basins are presented in Pradhananga and Pomeroy (2021).

For PGRB, ERA-Interim data were bias corrected to Peyto Main Station observations from 2013-2018 and ERA-40 data were bias-corrected to the archived observations from the station for the common overlap period of 1992-2001 (Munro, 2011). For AGRB, ERA-Interim data were bias-corrected to Athabasca Moraine Station. No in situ observations were available for the period before 2014 from AGRB. Therefore, ERA-40 data for 1965-1975 were bias-corrected using ERA-Interim data for the period of 1979-2002, similar to Krogh and Pomeroy (2018), using quantile mapping approach with monthly bias correction factors.

\section{Results and discussion}

Changes in climate (temperature and precipitation), changes in glacier configuration, and impacts on changes in runoff and glacier mass balance are discussed for both AGRB and PGRB.

\subsection{Change in climate}

Air temperature and precipitation over PGRB and AGRB were analyzed for the two periods - 1965-1975 and present 2008-2018. Daily mean (Tmean), maximum (Tmax), and minimum (Tmin) temperature (Figure 3 and Table 6-8) and monthly precipitation and cumulative precipitation (Figure 4 and Table 5), averaged and aggregated over the two 
climatic periods, were compared using the scheme S1. Daily mean temperature were obtained by averaging 24 hourly temperature values (Bernhardt et al., 2018).

Except during the summer maximum over AGRB, temperatures generally increased in the present decade compared to the past, for both annual and seasonal averages. Analysis at monthly time periods also shows that temperature at both glaciers increased significantly except for a few months. The exceptions in ABRB were Tmax in May, June and September; Tmin in February, October, November and December; and Tmean in February, May, June, October and December, when the present temperature values were either equal to or less than the past temperature values. The exceptions in PGRB were Tmax in December; Tmin in February and November; and Tmean in February and

December. Temperature increments are significantly different from zero and evident in more of the temperature variables in PGRB than in AGRB.

The precipitation data show that there was a slight increase in total annual precipitation in the present decade compared to the past over both basins (Figure 4). The monthly precipitation breakdown shows that winter (Dec-Feb) precipitation over both basins has decreased, but that precipitation in the other seasons has increased. Statistical analysis of seasonal precipitation change showed that an increase in summer precipitation in both basins and decrease in winter precipitation in AGRB were statistically significant, at the $5 \%$ level of significance (Table 5). The other changes in precipitation were not significant. Instead, there was an increase in rainfall, for both present climate and present glacier configuration, compared to the past climate and past glacier configuration in both research basins (Figure 5). Increase in the rainfall ratio in these basins are consistent with other studies, for example, in Europe by Hynčica and Huth (2019).

\subsection{Change in glacier configuration}

The glaciers have undergone significant mass loss in the last five decades, which is very noticeable at Peyto Glacier (e.g., Demuth and Keller, 2006; Kehrl et al., 2014) and comparatively less so at Athabasca Glacier (Tennant and Menounos, 2013).

During the period 1966-2014, Peyto Glacier shrank in area from $14.4 \mathrm{~km}^{2}\left(64.6 \%\right.$ of the total basin area of $\left.22.3 \mathrm{~km}^{2}\right)$ to $9.9 \mathrm{~km}^{2}$ (44.4\% of the basin area) and the accumulation area ratio (AAR) of the glacier dropped from 0.75 to 0.35 , exposing more ice in 2014, more than double the area exposed in 1966. The exposed ice area increased from $3.6 \mathrm{~km}^{2}$ to $6.4 \mathrm{~km}^{2}$, whereas the firn area decreased from $10.8 \mathrm{~km}^{2}$ to $3.5 \mathrm{~km}^{2}$.

Though to a lesser degree than Peyto Glacier, the area of Athabasca Glacier has also decreased in the last three decades (1984-2014) from $18 \mathrm{~km}^{2}$ (61.4\% of the total basin area of $\left.29.3 \mathrm{~km}^{2}\right)$ to $16.9 \mathrm{~km}^{2}(57.7 \%$ of the total basin area), and AAR decreased from 0.76 to 0.47 . The exposed ice area increased from $4.3 \mathrm{~km}^{2}$ to $9.0 \mathrm{~km}^{2}$, and the firn area decreased from $13.6 \mathrm{~km}^{2}$ to $7.9 \mathrm{~km}^{2}$. 
The firn line has moved to a higher elevation in both glaciers, and glacier surfaces have become steeper. The other change in the two glacier configurations was in elevation; the mean glacier surface elevation Peyto Glacier has decreased (from $2628 \mathrm{~m}$ to $2615 \mathrm{~m}$ ) while that of Athabasca Glacier has increased (from $2799 \mathrm{~m}$ to $2826 \mathrm{~m}$ ). In summary, glacier area is smaller now compared to the past, but firn area is also reduced, and ice-exposed area is increased in the present compared to the past. The details are in Table 4 and Figure 6,7 and 8.

\subsection{Change in runoff}

Figure 9 shows runoff and melt components from AGRB and PGRB with the two model scenarios, A and D (scheme S1). Snowmelt runoff dominated both the basins, in comparison to rainfall runoff, icemelt runoff, and firnmelt runoff. The present climate and present glacier configurations (model scenario A) produced more runoff than the past climate and past glacier configurations (model scenario D). There was a $19 \%$ increase significant at $\boldsymbol{\alpha}=5 \%(\mathrm{p}=0.005$, Table 9) in annual mean runoff, from $1581 \mathrm{~mm}$ to $1888 \mathrm{~mm}$ in PGRB (scheme S1, Figure 9). This was mainly due to an increased contribution from icemelt, from $265 \mathrm{~mm}$ to $667 \mathrm{~mm}$ ( $\mathrm{p}=0$, Table 9). There was a decrease in mean annual snowmelt, from $1105 \mathrm{~mm}$ to $974 \mathrm{~mm}$, but the change in this and the other fluxes were statistically insignificant. The increase in runoff was insignificant at $\boldsymbol{\alpha}=5 \%$ ( $\mathrm{p}=0.578$, Table 9) in the case of AGRB, from $1320 \mathrm{~mm}$ to $1365 \mathrm{~mm}$, though there was a significant increase in rainfall, from $175 \mathrm{~mm}$ to $262 \mathrm{~mm}$. AGRB experienced increased snowmelt and firnmelt but decreased icemelt.

In the case of AGRB, only increases in rainfall in the S3 and S4 schemes and in snowmelt in S4 were significant. More rainfall occurred with both past and present glacier configurations. There were significant changes in runoff, firn melt and snow melt for PGRB, suggesting that the increase in runoff over time (S3 and S4) was due to an increase in firn melt and ice melt. The large loss of firn in PGRB resulted in a decrease of firn melt by $65 \%$ (from $414 \mathrm{~mm}$ to $146 \mathrm{~mm}$ ) when the past glacier configuration was replaced by the present one with the climate for both glacier configurations held constant at the present climate.

Monthly averaged runoff from the four model scenarios is presented in Figure 10. There was a reduction in peak flows from both glaciers as glacier mass declined over time with the climate held constant. However, with changing climate only, peak flows increased over time. The peak flow of PGRB also shifted from August to July as climate shifted. This is in line with the prediction by Kienzle et al. (2012) for the Cline River watershed that spring runoff and peak streamflow would shift four weeks advance in the $21^{\text {st }}$ century compared to the baseline period (1961-1989). The combination of moving from past to present climate and changing glacier configuration shifted peak flows forward by a month, however, the impact of changing climate was greater than that of the changing glacier configuration.

The warmer temperatures and increased rainfall ratio in the present climate led to increased glacier runoff from both basins. However, the reduced glacier extent in the present glacier configuration resulted in decreased runoff in both basins, counteracting the direct climate change impact on the basin. 


\subsection{Change in glacier mass balance}

Seasonal and annual mass balance for AGRB and PGRB resulted from the four model scenarios, A-D, are presented in Figure 11. The results from the statistical analysis are presented in Table 11. Except for the change in winter mass balance between model scenarios A and D (scheme S1), the mass balance changes are not statistically significant in AGRB. There was a significant change in winter and annual mass balances between past and present climates and glaciers in PGRB (S1). Mean annual winter accumulation decreased from $586 \mathrm{~mm}$ [averaged over the past climate, 1965-1975] to $324 \mathrm{~mm}$ [averaged over the present climate, 2008-2018], resulting in negative mean annual mass balances, from $-271 \mathrm{~mm}$ in the past climate to $-733 \mathrm{~mm}$ in the present climate (Table 9). These changes are due more to the change in climate than the change in glacier configuration. Summer ablation increased significantly with present climate for both past and present glacier configurations (S3 and S4 scenarios). The changes are not significant in model runs using the S2 and S5 scenarios. However, the past glacier configuration resulted in greater winter snow accumulation in both basins for both past and present climates.

In summary, the outputs show that changes in climate and basin configurations are causing changes in the melt rate and runoff. Compared to the past climate and past glacier configuration, present climate and present glacier configuration provided more runoff in both basins, although there are significant losses of glacier mass.

\section{Conclusion}

This study investigated the influence of snow and glaciers on headwater hydrology in two mountain basins in the Canadian Rockies, where a warming climate and glacier retreat continue to cause concern about changes in high mountain hydrology.

There was an increase in air temperature, mainly in daily maximum and winter minimum temperatures. Total precipitation has not increased, but the rainfall ratio has increased with the shift in climate. Decreases in winter precipitation were balanced by increased precipitation in the other seasons. Both mass balance observations and analysis of satellite imagery show that the glaciers are losing mass, and that the exposure of ice at glacier surfaces has increased. The rate of these changes is lower in AGRB than in PGRB. The retreat of the glaciers has led to reductions in glacierized areas and changes in elevation and slope of the glacier surfaces. The decreases in AAR over time as the glacier changed configuration, caused increases in both proportional and areal ice exposure.

The study used a novel approach to apply present climate to feed past glacier configuration and past climate to feed present glacier configuration, so that the impacts of changes in glacier configuration and climate on glacier hydrology could be explicitly separated. The modelling results presented here show that glacier retreat and ablation are due to the joint effect of warming climate and an increase in ice exposure, which increased both seasonal melt and runoff. Increased streamflow discharge was due to climate warming and is limited somewhat by glacier retreat. Model results indicated that streamflow from the glaciers was still increasing in the present climate (2008-2018) compared to the 
past climate (1965-1975) despite reductions in glacier area and volume. Such a modelling approach is important for diagnosing the hydrological responses from a glacierized basin in the context of climate change and variability.

\section{Author contribution}

5 DP and JWP conceptualized the research. DP did the analysis and prepared the manuscript. JWP edited and revised the manuscript.

\section{Competing interests}

The authors declare that they have no conflict of interest.

10

\section{Acknowledgements}

The authors wish to acknowledge the decades of extremely challenging field research at Peyto and Athabasca glacier basins by dozens of scientists and students over the decades. Meriting special mention are Dr. D. Scott Munro of the University of Toronto and Michael N. Demuth of Natural Resources Canada whose legacy of research on Peyto Glacier including meteorological and mass balance observations made this study possible. Special mention also goes to the prescient scientists of the International Hydrological Decade who established Peyto Glacier as a research site, including Dr. Gordon Young of Environment Canada and Wilfrid Laurier University. Additional data were provided by Environment and Climate Change Canada's Meteorological Service of Canada and Water Survey of Canada, Parks Canada and Alberta Environment and Parks. Tom Brown and Xing Fang of the Centre for Hydrology supported CRHM development and operation/parameterization, respectively. Funding for this study was provided by the Canada Research Chairs, Canada Foundation for Innovation, Natural Sciences and Engineering Research Council of Canada through its Discovery Grants and the Changing Cold Regions Network and the Canada First Research Excellence Fund's Global Water Futures Programme. 


\section{References}

Anderson, E. R.: Modelling Changes in Multi-Decadal Streamflow Contributions - Bologna Glacier, Selwyn Mountains, NWT, Canada, University of Saskatchewan. [online] Available from: https://ecommons.usask.ca/handle/10388/7919, 2017.

Arendt, A., Echelmeyer, K., Harrison, W., Lingle, C. and Valentine, V. B.: Rapid wastage of Alaska glaciers and their contribution to rising sea level., Science, 297(5580), 382-6, doi:10.1126/science.1072497, 2002.

Barry, R. G.: The status of research on glaciers and global glacier recession: a review, Prog. Phys. Geogr., 30(3), 285-306, doi:10.1191/0309133306pp478ra, 2006.

Bernhardt, J., Carleton, A. M. and LaMagna, C.: A comparison of daily temperature-averaging methods: Spatial variability and recent change for the CONUS, J. Clim., 31(3), 979-996, doi:10.1175/JCLI-D-17-0089.1, 2018. Bolch, T., Menounos, B. and Wheate, R.: Landsat-based inventory of glaciers in western Canada, 1985-2005, Remote Sens. Environ., 114(1), 127-137, doi:10.1016/j.rse.2009.08.015, 2010.

Casassa, G., Paulina, L., Pouyaud, B. and Escobar, F.: Detection of changes in glacial run-off in alpine basins : examples from North America , the Alps , central Asia and the Andes, , 41, 31-41, doi:10.1002/hyp, 2009.

Clarke, G. K. C., Jarosch, A. H., Anslow, F. S., Radić, V. and Menounos, B.: Projected deglaciation of western Canada in the twenty-first century, Nat. Geosci., 8(5), 372-377, doi:10.1038/ngeo2407, 2015.

Comeau, L. E. L., Pietroniro, A. and Demuth, M. N.: Glacier contribution to the North and South Saskatchewan Rivers, in Hydrological Processes, vol. 23, pp. 2640-2653., 2009.

DeBeer, C. M. and Sharp, M. J.: Recent changes in glacier area and volume within the southern Canadian Cordillera, Ann. Glaciol., 46(1), 215-221, doi:10.3189/172756407782871710, 2007.

Dee, D. P., Uppala, S. M., Simmons, A. J., Berrisford, P., Poli, P., Kobayashi, S., Andrae, U., Balmaseda, M. A., Balsamo, G., Bauer, P., Bechtold, P., Beljaars, A. C. M., van de Berg, L., Bidlot, J., Bormann, N., Delsol, C., Dragani, R., Fuentes, M., Geer, A. J., Haimberger, L., Healy, S. B., Hersbach, H., Hólm, E. V., Isaksen, L., Kållberg, P., Köhler, M., Matricardi, M., Mcnally, A. P., Monge-Sanz, B. M., Morcrette, J. J., Park, B. K., Peubey, C., de Rosnay, P., Tavolato, C., Thépaut, J. N. and Vitart, F.: The ERA-Interim reanalysis: Configuration and performance of the data assimilation system, Q. J. R. Meteorol. Soc., 137(April), 553-597, doi:10.1002/qj.828, 2011.

Demuth, M. N. and Keller, R.: An assessment of the mass balance of Peyto glacier (1966-1995) and its relation to Recent and past-century climatic variability, in Peyto Glacier: One Century of Science, edited by M. N. Demuth, D.

30 S. Munro, and G. J. Young, pp. 83-132, National Hydrology Research Institute, Saskatoon, Saskatchewan., 2006. Demuth, M. N. and Pietroniro, A.: The impact of climate change on the glaciers of the Canadian Rocky Mountain eastern slopes and implications for water resource-related adaptation in the Canadian prairies "Phase I " Headwaters of the North Saskatchewan River Basin. [online] Available from: http://www.parc.ca/pdf/research_publications/water1.pdf, 2003.

35 Derksen, C., Smith, S. L., Sharp, M., Brown, L., Howell, S., Copland, L., Mueller, D. R., Gauthier, Y., Fletcher, C. G., Tivy, A., Bernier, M., Bourgeois, J., Brown, R., Burn, C. R., Duguay, C., Kushner, P., Langlois, A., Lewkowicz, a. G., Royer, A. and Walker, A.: Variability and change in the Canadian cryosphere, Clim. Change, 115(1), 59-88, 
doi:10.1007/s10584-012-0470-0, 2012.

Fang, X., Pomeroy, J. W., Ellis, C. R., MacDonald, M. K., DeBeer, C. M. and Brown, T.: Multi-variable evaluation of hydrological model predictions for a headwater basin in the Canadian Rocky Mountains, Hydrol. Earth Syst. Sci., 17(4), 1635-1659, doi:10.5194/hess-17-1635-2013, 2013.

Fountain, A. G. and Tangborn, W. V.: The effect of glaciers on streamflow variations, Water Resour. Res., 21(4), 579-586, doi:10.1029/WR021i004p00579, 1985.

Hopkinson, C. and Young, G. J.: The effect of glacier wastage on the flow of the Bow River at Banff, Alberta, 19511993, Hydrol. Process., 12(10-11), 1745-1762, doi:10.1002/(SICI)1099-1085(199808/09)12:10/11<1745::AIDHYP692>3.0.CO;2-S, 1998.

10 Hynčica, M. and Huth, R.: Long-term changes in precipitation phase in Europe in cold half year, Atmos. Res., doi:10.1016/j.atmosres.2019.04.032, 2019.

Immerzeel, W. W., Pellicciotti, F. and Bierkens, M. F. P.: Rising river flows throughout the twenty-first century in two Himalayan glacierized watersheds, Nat. Geosci., 6(9), 742-745, doi:10.1038/ngeo1896, 2013.

Kehrl, L. M., Hawley, R. L., Osterberg, E. C., Winski, D. A. and Lee, A. P.: Volume loss from lower Peyto Glacier, Alberta, Canada, between 1966 and 2010, J. Glaciol., 60(219), 51-56, doi:10.3189/2014JoG13J039, 2014.

Kienzle, S. W., Nemeth, M. W., Byrne, J. M. and Macdonald, R. J.: Simulating the hydrological impacts of climate change in the upper North Saskatchewan River basin, Alberta, Canada, J. Hydrol., 412-413, 76-89, doi:10.1016/j.jhydrol.2011.01.058, 2012.

Krogh, S. A. and Pomeroy, J. W.: Recent changes to the hydrological cycle of an Arctic basin at the tundra-taiga transition, Hydrol. Earth Syst. Sci., 22, 3993-4014, doi:10.5194/hess-22-3993-2018, 2018.

Krogh, S. A., Pomeroy, J. W. and McPhee, J.: Physically Based Mountain Hydrological Modeling Using Reanalysis Data in Patagonia, J. Hydrometeorol., 16, 172-193, doi:10.1175/JHM-D-13-0178.1, 2015.

Luo, Y., Arnold, J., Liu, S., Wang, X. and Chen, X.: Inclusion of glacier processes for distributed hydrological modeling at basin scale with application to a watershed in Tianshan Mountains, northwest China, J. Hydrol., 477, 72-85, doi:10.1016/j.jhydrol.2012.11.005, 2013.

Marks, D., Winstral, A., Flerchinger, G., Reba, M., Pomeroy, J., Link, T. and Elder, K.: Comparing Simulated and Measured Sensible and Latent Heat Fluxes over Snow under a Pine Canopy to Improve an Energy Balance Snowmelt Model, J. Hydrometeorol., 9(6), 1506-1522, doi:10.1175/2008JHM874.1, 2008.

Marshall, S. J., White, E. C., Demuth, M. N., Bolch, T., Wheate, R., Menounos, B., Beedle, M. J. and Shea, J. M.:

Glacier Water Resources on the Eastern Slopes of the Canadian Rocky Mountains, Can. Water Resour. J., 36(March 2010), 109-134, doi:10.4296/cwrj3602823, 2011.

Moore, R. D. and Demuth, M. N.: Mass balance and streamflow variability at Place Glacier, Canada, in relation to recent climate fluctuations, Hydrol. Process., 15(18), 3473-3486, doi:10.1002/hyp.1030, 2001.

Moore, R. D., Fleming, S. W., Menounos, B., Wheate, R., Fountain, A., Stahl, K., Holm, K. and Jakob, M.: Glacier change in western North America : influences on hydrology, geomorphic hazards and water quality, Hydrol. Process., 23, 42-61, doi:10.1002/hyp.7162, 2009.

Munro, D. S.: Progress in glacier hydrology : a Canadian perspective, Hydrol. Process., 14, 1627-1640, 2000. 
Munro, D. S.: Peyto Creek hydrometeorological database (Peyto Creek Base Camp AWS), IP3 Arch. [online] Available from: www.usask.ca/ip3/data, 2011.

Pomeroy, J. W., Gray, D. M., Brown, T., Hedstrom, N. R., Quinton, W. L., Granger, R. J. and Carey, S. K.: The cold regions hydrological model: a platform for basing process representation and model structure on physical evidence, Hydrol. Process., 21(19), 2650-2667, doi:10.1002/hyp.6787, 2007.

Pomeroy, J. W., Fang, X. and Rasouli, K.: Sensitivity of snow processes to warming in the Canadian Rockies, 72nd East. Snow Conf. Sherbrooke, Quebec, Canada, 22-33, 2015.

Pradhananga, D. and Pomeroy, J. W.: Diagnosing Changes in Glacier Hydrology from Physical Principles, using a Hydrological Model with Snow Redistribution, Sublimation, Firnification and Energy Balance Ablation Algorithms, J. Hydrol., Submitted, 2021.

R Core Team: R: A language and environment for statistical computing, 2017.

Rasouli, K., Pomeroy, J. W., Janowicz, J. R., Carey, S. K. and Williams, T. J.: Hydrological sensitivity of a northern mountain basin to climate change, Hydrol. Process., 28(14), 4191-4208, doi:10.1002/hyp.10244, 2014.

Reynolds, J. R. and Young, G. J.: Changes in areal extent, elevation and volume of Athabasca Glacier, Alberta,

15 Canada, as estimated from a series of maps produced between 1919 and 1979, Ann. Glaciol., 24, 60-65, 1997.

Riedel, J. L., Wilson, S., Baccus, W., Larrabee, M., Fudge, T. J., Fountain, A. and Riedel, C. J. L.: Glacier status and contribution to streamflow in the Olympic Mountains , Washington , USA, J. Glaciol., 61(225), 8-16, doi:10.3189/2015JoG14J138, 2015.

Schiefer, E., Menounos, B. and Wheate, R.: Recent volume loss of British Columbian glaciers, Canada, Geophys.

Res. Lett., 34(16), 1-6, doi:10.1029/2007GL030780, 2007.

Sedgwick, J. K. and Henoch, W. E. S.: 1966 Peyto Glacier Map, Banff National Park, Alberta. Environment Canada, IWD 1010, 1:10,000., 1975.

Stahl, K. and Moore, R. D.: Influence of watershed glacier coverage on summer streamflow in British Columbia, Canada, Water Resour. Res., 42(6), 1-5, doi:10.1029/2006WR005022, 2006.

Tennant, C. and Menounos, B.: Glacier change of the Columbia Icefield, Canadian Rocky Mountains, 1919-2009, J. Glaciol., 59(216), 671-686, doi:10.3189/2013JoG12J135, 2013.

Uppala, S. M., KÅllberg, P. W., Simmons, A. J., Andrae, U., Bechtold, V. D. C., Fiorino, M., Gibson, J. K., Haseler, J., Hernandez, A., Kelly, G. A., Li, X., Onogi, K., Saarinen, S., Sokka, N., Allan, R. P., Andersson, E., Arpe, K., Balmaseda, M. A., Beljaars, A. C. M., Berg, L. Van De, Bidlot, J., Bormann, N., Caires, S., Chevallier, F., Dethof, A., Dragosavac, M., Fisher, M., Fuentes, M., Hagemann, S., Hólm, E., Hoskins, B. J., Isaksen, L., Janssen, P. A. E. M., Jenne, R., Mcnally, A. P., Mahfouf, J.-F., Morcrette, J.-J., Rayner, N. A., Saunders, R. W., Simon, P., Sterl, A., Trenberth, K. E., Untch, A., Vasiljevic, D., Viterbo, P. and Woollen, J.: The ERA-40 re-analysis, Q. J. R. Meteorol. Soc., 131(612), 2961-3012, doi:10.1256/qj.04.176, 2005.

Vincent, L. A., Zhang, X., Brown, R. D., Feng, Y., Mekis, E., Milewska, E. J., Wan, H. and Wang, X. L.: Observed trends in Canada's climate and influence of low-frequency variability modes, J. Clim., 28(11), 4545-4560, doi:10.1175/JCLI-D-14-00697.1, 2015. de Woul, M., Hock, R., Braun, M., Thorsteinsson, T., Jóhannesson, T. and Halldórsdóttir, S.: Firn layer impact on 
https://doi.org/10.5194/hess-2021-349

Preprint. Discussion started: 27 July 2021

(c) Author(s) 2021. CC BY 4.0 License.

glacial runoff: a case study at Hofsjökull, Iceland, Hydrol. Process., 20(10), 2171-2185, doi:10.1002/hyp.6201, 2006.

Zhou, J., Pomeroy, J. W., Zhang, W., Cheng, G., Wang, G. and Chen, C.: Simulating cold regions hydrological processes using a modular model in the west of China, J. Hydrol., 509, 13-24, doi:10.1016/j.jhydrol.2013.11.013,

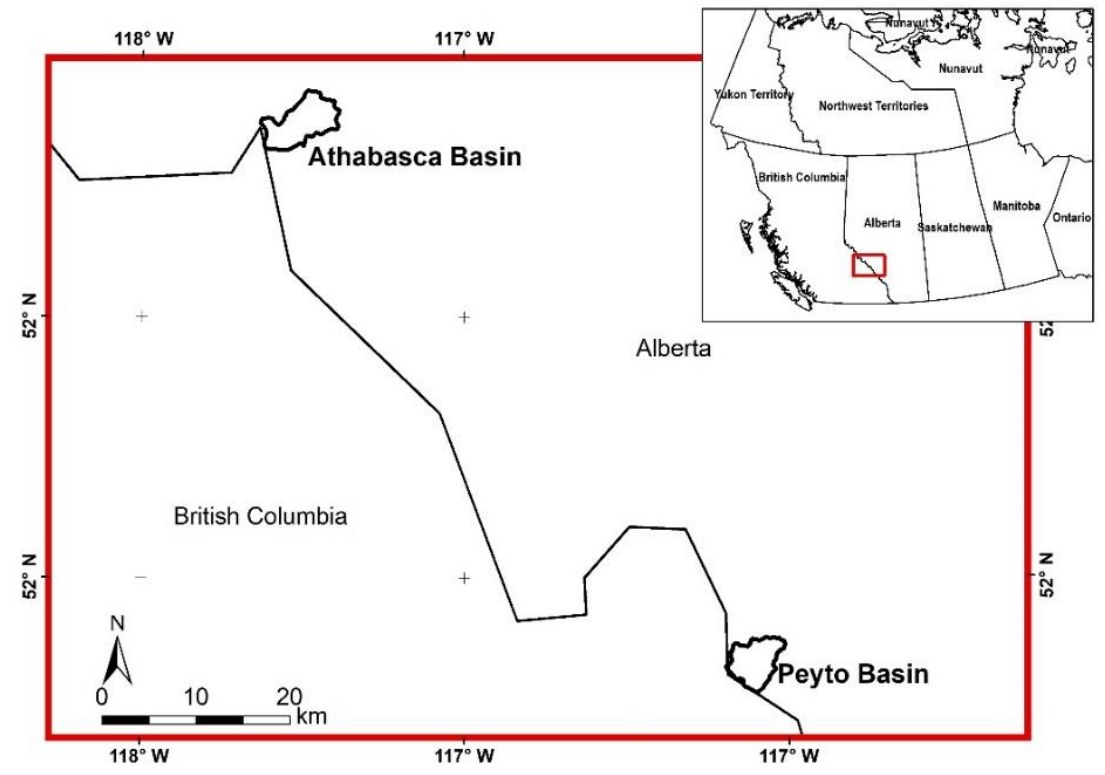

Figure 1: Location map of Peyto and Athabasca glacier research basins.

10

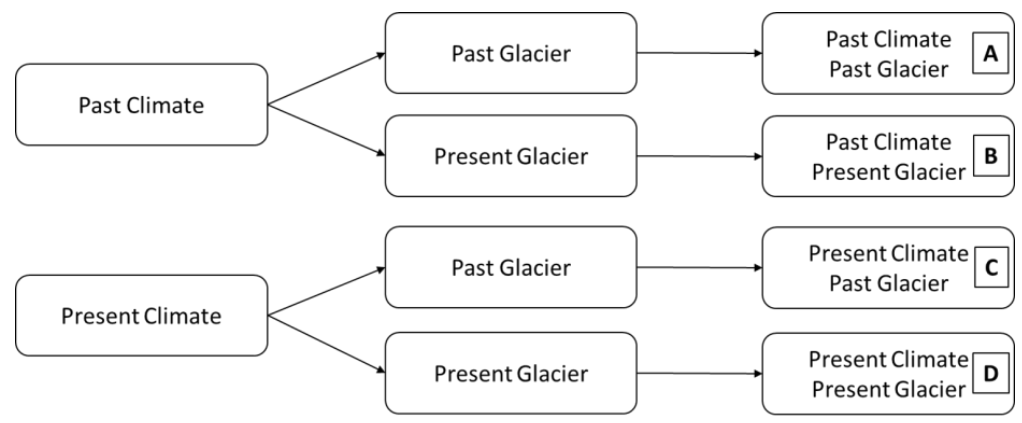

Figure 2: Four model scenarios combining past and present climate and glacier 

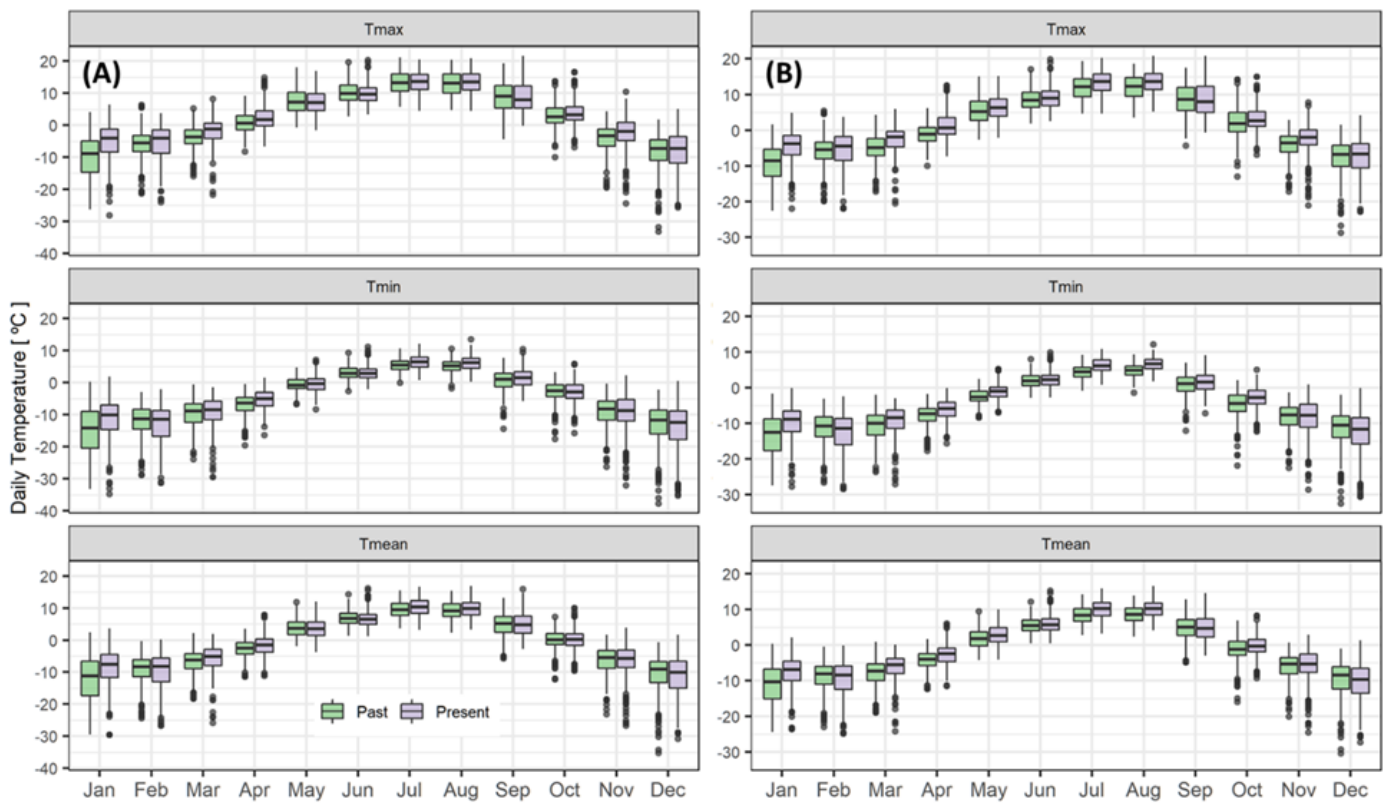

Figure 3: Seasonal daily maximum, minimum and mean temperature comparison between two periods: past (1965-1975) and present (2008-2018). (A) AGRB (B) PGRB. 

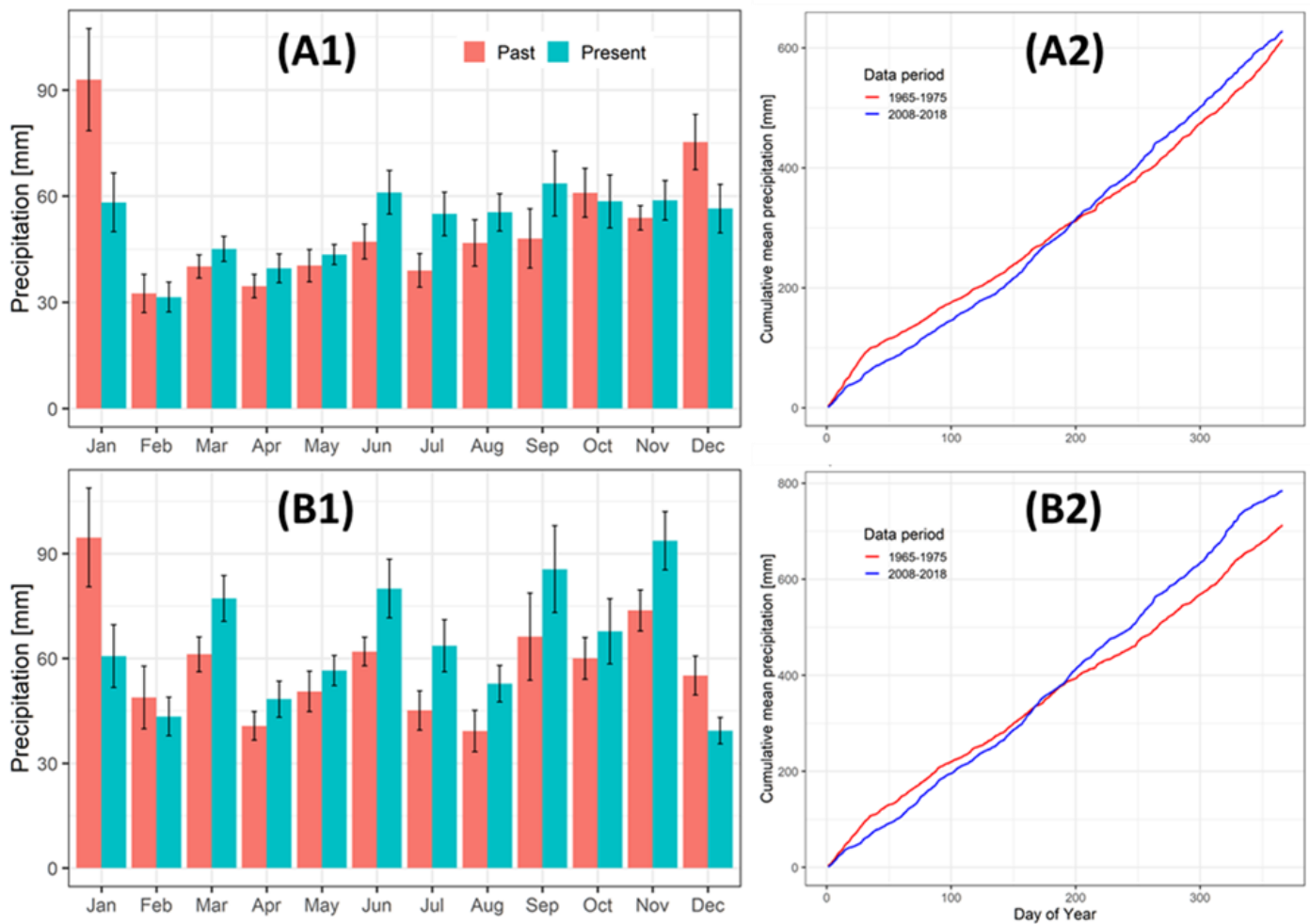

Figure 4: Monthly and cumulative daily mean precipitation averaged over the two periods: past (1965-1975) and present (2008-2018). (A) AGRB (B) PGRB. A1 and B1 are monthly totals, red is for the past and blue is for the present. A2 and B2 are the averaged cumulative precipitation.
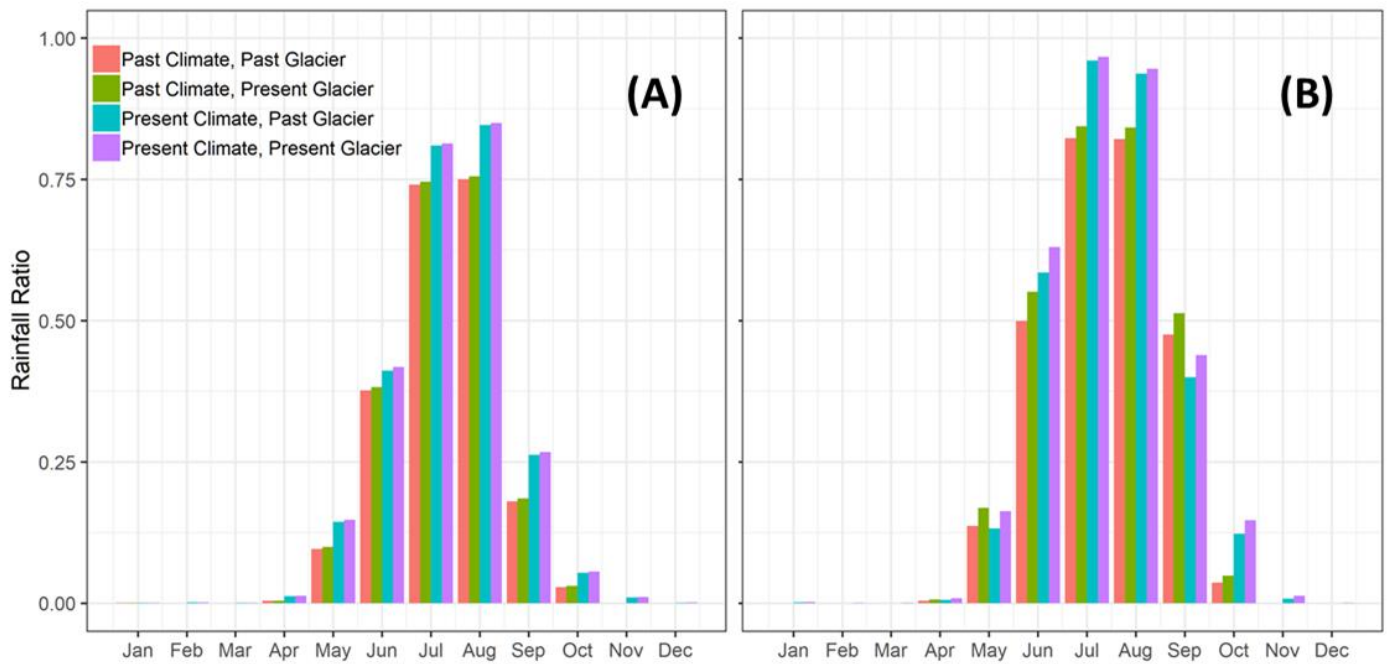

Figure 5: Mean-monthly rainfall ratios simulated for the four model run scenarios. (A) AGRB, (B) PGRB. 
https://doi.org/10.5194/hess-2021-349

Hydrology and

Preprint. Discussion started: 27 July 2021

(c) Author(s) 2021. CC BY 4.0 License.
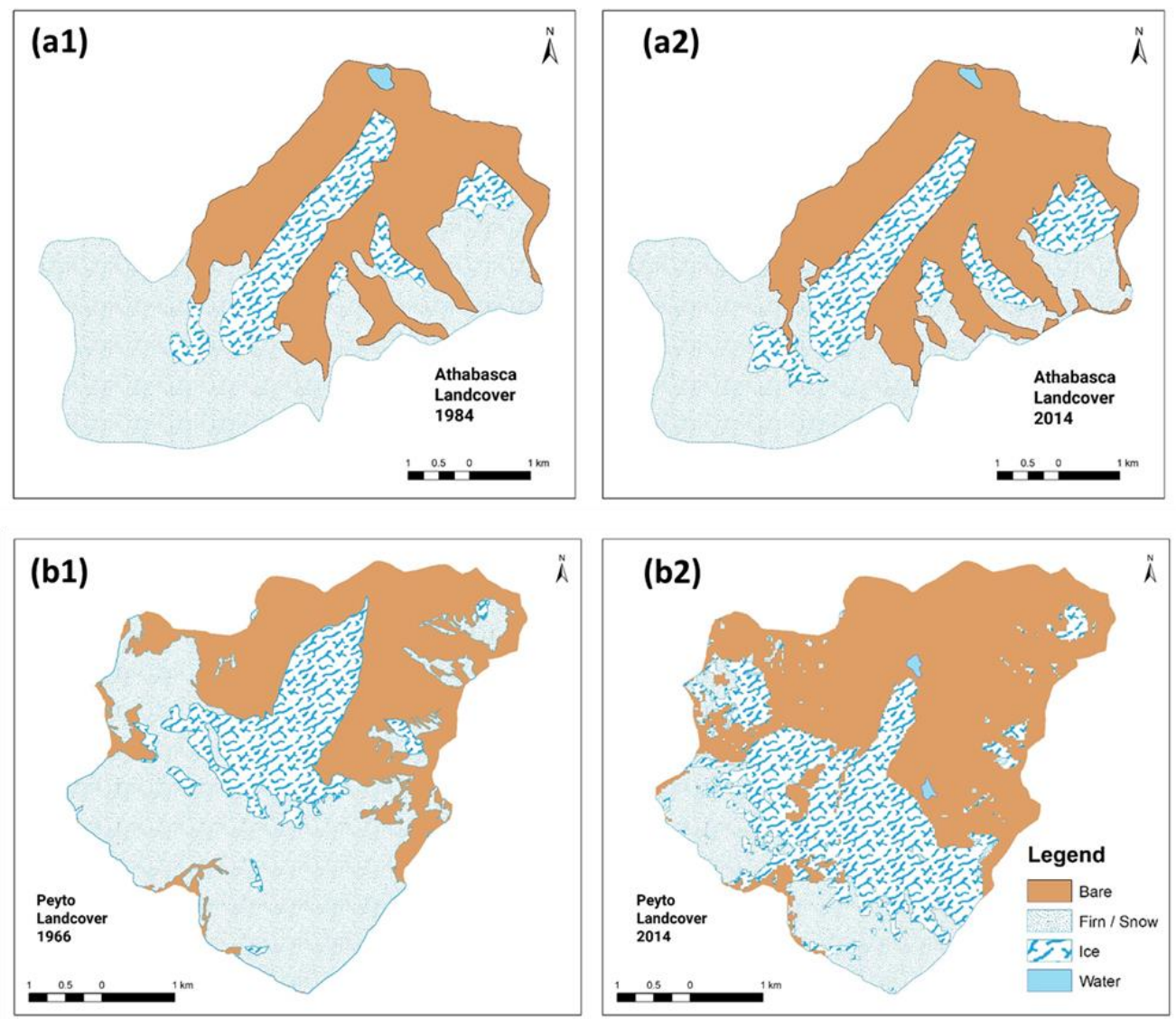

Figure 6: Change in landcover between the glaciers in past and present. (a) AGRB (b) PGRB. (a1) and (a2) are AGRB in 1984 and 2014, respectively. (b1) and (b2) are PGRB in 1966 and 2014, respectively. 
https://doi.org/10.5194/hess-2021-349

Preprint. Discussion started: 27 July 2021

(c) Author(s) 2021. CC BY 4.0 License.
Hydrology and Earth System Sciences
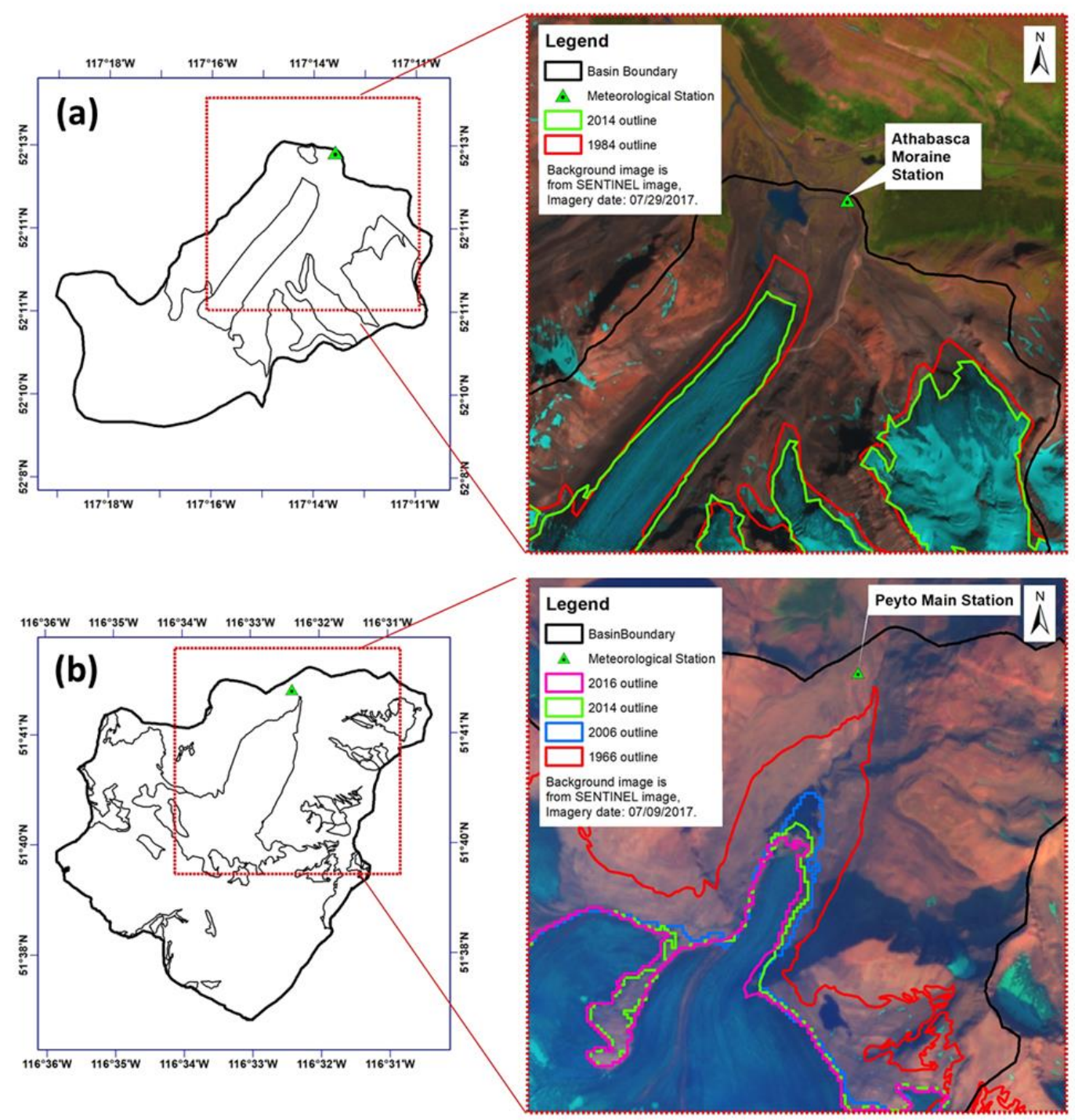

Figure 7: Change in landcover between the glaciers in past and present. (a) AGRB (b) PGRB. 
https://doi.org/10.5194/hess-2021-349

Preprint. Discussion started: 27 July 2021

(c) Author(s) 2021. CC BY 4.0 License.
Hydrology and

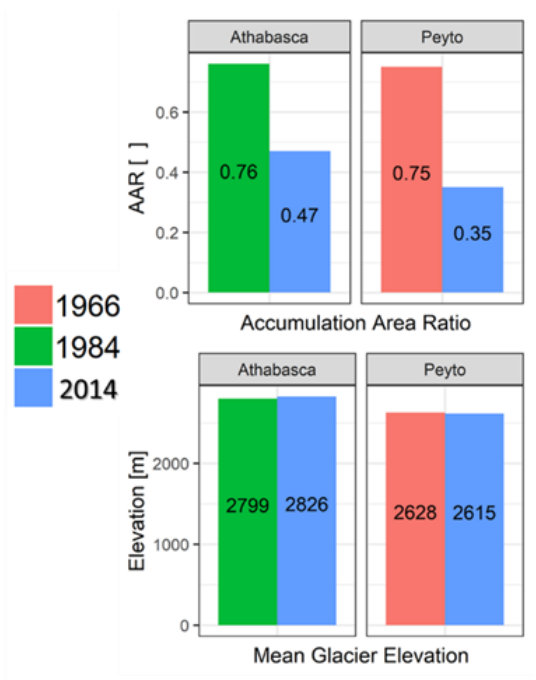

Figure 8: Comparison of glacier configurations at two times. PGRB is compared between 1966 and 2014; AGRB is compared between 1984 and 2014. Red is for 1966, green is for 1984, and blue is for 2014.
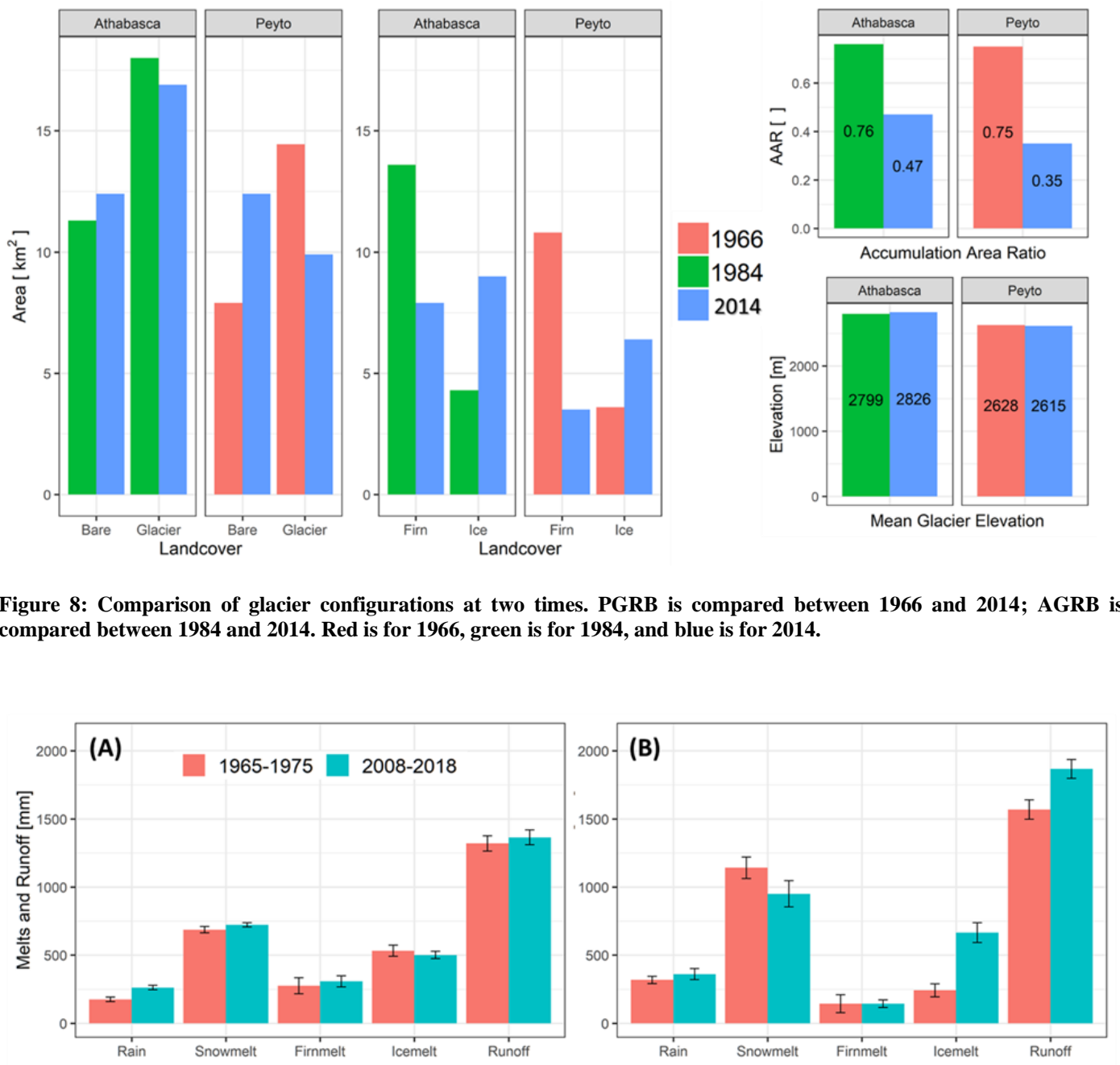

Figure 9: Mean annual melt and runoff in the past and the present. Error bars show the annual variability, defined as the standard error between years. (A) AGRB (B) PGRB. 
https://doi.org/10.5194/hess-2021-349

Preprint. Discussion started: 27 July 2021

(c) Author(s) 2021. CC BY 4.0 License.
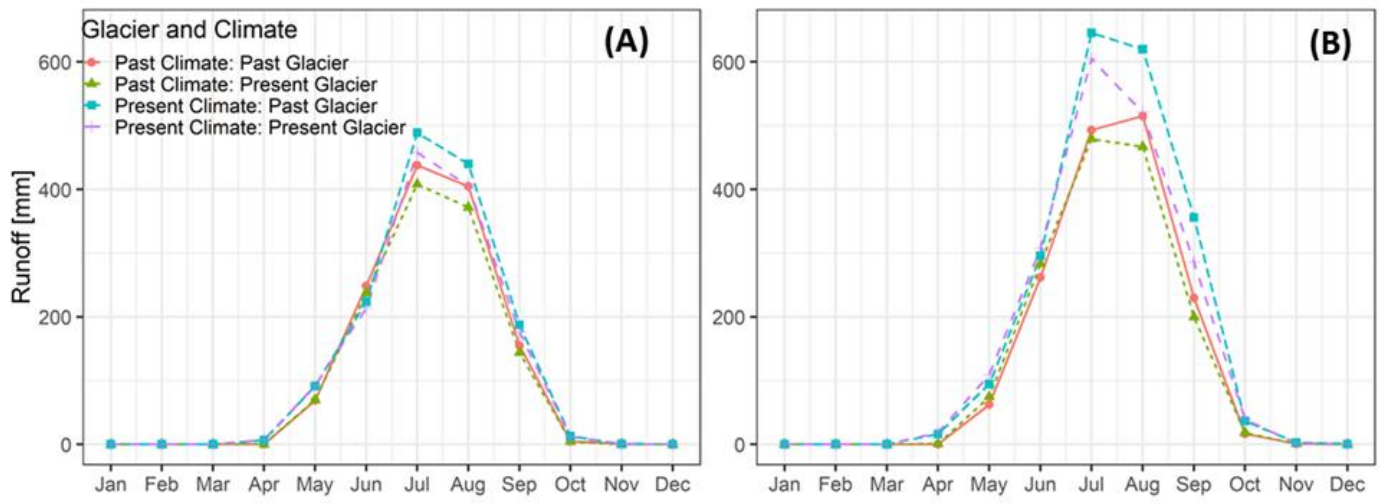

Figure 10: Monthly averaged runoff from the four model scenarios. (A) AGRB (B) PGRB.
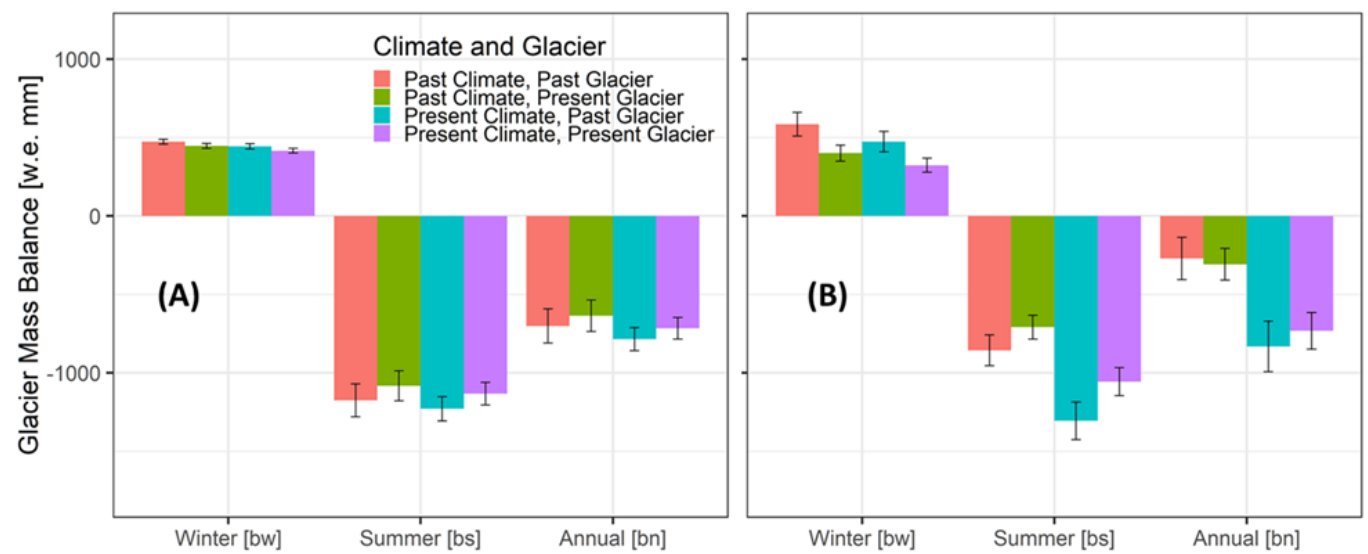

Figure 11: Glacier mass balance - winter, summer and annual, from the four model scenarios. (A) AGRB and (B) PGRB. 
Table 1: Physical characteristics of the study basins

\begin{tabular}{|l|l|l|}
\hline Basin configuration & PGRB & AGRB \\
\hline Basin Area & $22.43 \mathrm{~km}^{2}$ & $29.3 \mathrm{~km}^{2}$ \\
\hline Glacier & $9.9 \mathrm{~km}^{2}[44 \%$ ] as of 2014 & $16.9 \mathrm{~km}^{2}[58 \%]$ as of 2014 \\
\hline Elevation range of basin & $1907-3152 \mathrm{~m}$ as of 2014 & $1926-3459 \mathrm{~m}$ as of 2011 \\
\hline Location & $\begin{array}{l}51^{\circ} 40^{\prime} \mathrm{N}, 116^{0} 33^{\prime} \mathrm{W} \\
\text { Banff National Park, Alberta, Canada }\end{array}$ & $\begin{array}{l}52^{0} 11^{\prime} \mathrm{N}, 117^{\circ} 16^{\prime} \mathrm{W} \\
\text { Jasper National Park, Alberta, Canada }\end{array}$ \\
\hline Mean elevation of glacier & $2615 \mathrm{~m}$ [2014 DEM and Landcover] & $2826 \mathrm{~m}$ [2011 DEM, 2014 Landcover] \\
\hline Basin outlets & $\begin{array}{l}\text { Old gauge: } \\
51^{\circ} 41^{\prime} 37^{\prime \prime} \mathrm{N} ; 116^{\circ} 32^{\prime} 08^{\prime \prime} \mathrm{W} \\
\text { New gauge: }\end{array}$ & $52^{\circ} 122^{\prime} 58^{\prime \prime}$; $117^{\circ} 13^{\prime} 55^{\prime \prime} \mathrm{W}$ \\
\hline $51^{\circ} 40^{\prime} 52^{\prime \prime} \mathrm{N} ; 116^{\circ} 32^{\prime} 41^{\prime \prime} \mathrm{W}$ & \\
\hline
\end{tabular}

Table 2: DEM and landcover maps of two times

\begin{tabular}{|c|c|c|c|c|}
\hline & & \multirow{2}{*}{ Climate } & \multicolumn{2}{|c|}{ Glacier Configuration } \\
\hline & & & DEM & Landcover \\
\hline \multirow{2}{*}{ Present } & Athabasca & \multirow{2}{*}{ 2008-2018 } & 2011 & 2014 \\
\hline & Peyto & & 2014 & 2014 \\
\hline \multirow{2}{*}{ Past } & Athabasca & \multirow{2}{*}{$1965-1975$} & 1983 & 1984 \\
\hline & Peyto & & 1966 & 1966 \\
\hline
\end{tabular}

Table 3: Schemes for comparison of model outputs

\begin{tabular}{|l|lll|}
\hline Schemes & Comparison of model scenarios & & \\
\hline S1 & Past Climate-Past Glacier [A] & VERSUS & Present Climate-Present Glacier [D] \\
\hline S2 & Past Climate-Past Glacier [A] & VERSUS & Past Climate-Present Glacier [B] \\
\hline S3 & Past Climate-Past Glacier [A] & VERSUS & Present Climate-Past Glacier [C] \\
\hline S4 & Past Climate-Present Glacier [B] & VERSUS & Present Climate-Present Glacier [D] \\
\hline S5 & Present Climate-Past Glacier [C] & VERSUS & Present Climate-Present Glacier [D] \\
\hline
\end{tabular}


Table 4: Changes in glacier configurations

\begin{tabular}{|l|r|r|r|r|}
\hline \multirow{2}{*}{ Landcover } & \multicolumn{2}{|c|}{ Athabasca } & \multicolumn{2}{c|}{ Pevto } \\
\cline { 2 - 5 } & $\underline{\mathbf{1 9 8 4}}$ & $\underline{\mathbf{2 0 1 4}}$ & $\underline{\mathbf{1 9 6 6}}$ & $\underline{\mathbf{2 0 1 4}}$ \\
\hline Firn area $\left(\mathrm{km}^{2}\right)$ & 13.6 & 7.9 & 10.8 & 3.5 \\
\hline Exposed ice $\left(\mathrm{km}^{2}\right)$ & 4.3 & 9.0 & 3.6 & 6.4 \\
\hline Glacier" ${ }^{*}\left(\mathrm{~km}^{2}\right)$ & 18.0 & 16.9 & 14.4 & 9.9 \\
\hline Accumulation Area Ratio (AAR) & 0.76 & 0.47 & 0.75 & 0.35 \\
\hline Non-glacial area $\left(\mathrm{km}^{2}\right)$ & 11.3 & 12.4 & 7.9 & 12.4 \\
\hline Total basin area ${ }^{\&}\left(\mathrm{~km}^{2}\right)$ & 29.3 & 29.3 & 22.3 & 22.3 \\
\hline Mean glacier elevation $(\mathrm{m})$ & 2798.9 & 2825.5 & 2627.6 & 2615.1 \\
\hline Slope $\left({ }^{\circ}\right)$ & 21.1 & 21.6 & 19.9 & 22.0 \\
\hline
\end{tabular}

\#Glacier area is the sum of firn area and ice exposed area.

${ }^{\&}$ Total basin area is the sum of glacier area and nonglacial area.

Table 5: Changes in precipitation in annual, seasonal and monthly time periods [Scheme S1]

\begin{tabular}{|l|r|r|r|r|r|r|r|r|}
\hline \multirow{2}{*}{ Seasons } & \multicolumn{5}{|c|}{ Athabasca } & \multicolumn{4}{c|}{ Peyto } \\
\cline { 2 - 11 } & $\begin{array}{r}\text { p-value } \\
\text { Wilcox test }\end{array}$ & $\begin{array}{c}\text { p-value } \\
\text { t-test }\end{array}$ & $\begin{array}{c}\text { Mean 1 } \\
(\mathrm{mm})\end{array}$ & $\begin{array}{c}\text { Mean 2 } \\
(\mathrm{mm})\end{array}$ & $\begin{array}{c}\text { p-value } \\
\text { Wilcox test }\end{array}$ & $\begin{array}{c}\text { p-value } \\
\text { t-test }\end{array}$ & $\begin{array}{c}\text { Mean 1 } \\
(\mathrm{mm})\end{array}$ & $\begin{array}{c}\text { Mean } 2 \\
(\mathrm{~mm})\end{array}$ \\
\hline Annual & 0.912 & 0.683 & 611.4 & 626.6 & 0.143 & 0.121 & 697.0 & 768.7 \\
\hline Winter & 0.043 & 0.037 & 254.5 & 205.0 & 0.436 & 0.223 & 272.2 & 237.0 \\
\hline Spring & 0.089 & 0.191 & 115.0 & 128.1 & 0.064 & 0.057 & 152.4 & 182.1 \\
\hline Summer & 0.052 & 0.020 & 132.9 & 171.4 & 0.009 & 0.006 & 146.2 & 196.4 \\
\hline Fall & 0.481 & 0.468 & 109.0 & 122.1 & 0.218 & 0.260 & 126.2 & 153.2 \\
\hline January & 0.123 & 0.056 & 92.9 & 58.2 & 0.089 & 0.060 & 94.6 & 60.7 \\
\hline February & 0.821 & 0.882 & 32.5 & 31.5 & 1.000 & 0.613 & 48.8 & 43.4 \\
\hline March & 0.436 & 0.313 & 40.1 & 45.1 & 0.165 & 0.069 & 61.2 & 77.2 \\
\hline April & 0.496 & 0.356 & 34.6 & 39.6 & 0.280 & 0.259 & 40.7 & 48.3 \\
\hline May & 0.436 & 0.571 & 40.4 & 43.5 & 0.393 & 0.420 & 50.6 & 56.5 \\
\hline June & 0.043 & 0.095 & 47.1 & 61.0 & 0.029 & 0.076 & 61.9 & 80.0 \\
\hline July & 0.054 & 0.055 & 39.0 & 55.0 & 0.089 & 0.064 & 45.1 & 63.6 \\
\hline August & 0.353 & 0.319 & 46.7 & 55.4 & 0.123 & 0.103 & 39.2 & 52.8 \\
\hline September & 0.280 & 0.227 & 48.0 & 63.6 & 0.315 & 0.288 & 66.2 & 85.5 \\
\hline October & 0.739 & 0.814 & 60.9 & 58.5 & 0.529 & 0.497 & 60.0 & 67.7 \\
\hline November & 0.579 & 0.462 & 53.9 & 58.8 & 0.063 & 0.067 & 73.7 & 93.7 \\
\hline December & 0.082 & 0.086 & 75.3 & 56.5 & 0.035 & 0.032 & 55.1 & 39.3 \\
\hline
\end{tabular}


Table 6: Changes in daily maximum temperature in annual, seasonal and monthly periods [Scheme S1]

\begin{tabular}{|l|r|r|r|r|r|r|r|r|}
\hline \multirow{2}{*}{ Seasons } & \multicolumn{5}{|c|}{ Athabasca } & \multicolumn{4}{|c|}{ Peyto } \\
\cline { 2 - 9 } & $\begin{array}{r}\text { p-value } \\
\text { Wilcox test }\end{array}$ & $\begin{array}{c}\text { p-value } \\
\text { t-test }\end{array}$ & \multicolumn{1}{c|}{$\begin{array}{c}\text { Mean 1 } \\
\left({ }^{\circ} \mathrm{C}\right)\end{array}$} & $\begin{array}{c}\text { Mean } 2 \\
\left({ }^{\circ} \mathrm{C}\right)\end{array}$ & $\begin{array}{c}\text { p-value } \\
\text { Wilcox test }\end{array}$ & $\begin{array}{c}\text { p-value } \\
\text { t-test }\end{array}$ & $\begin{array}{c}\text { Mean 1 } \\
\left({ }^{\circ} \mathrm{C}\right)\end{array}$ & $\begin{array}{c}\text { Mean } 2 \\
\left({ }^{\circ} \mathrm{C}\right)\end{array}$ \\
\hline Annual & 0.002 & 0.002 & 2.1 & 3.1 & 0.000 & 0.000 & 1.3 & 2.8 \\
\hline Winter & 0.009 & 0.009 & -7.2 & -5.3 & 0.001 & 0.001 & -0.2 & 1.7 \\
\hline Spring & 0.052 & 0.044 & 1.5 & 2.6 & 0.043 & 0.016 & 11 & 12.1 \\
\hline Summer & 0.796 & 0.979 & 12.3 & 12.3 & 0.315 & 0.358 & 5.3 & 5.9 \\
\hline Fall & 0.436 & 0.529 & 5.9 & 6.3 & 0.007 & 0.005 & -6.8 & -5 \\
\hline January & 0.000 & 0.001 & -10.1 & -5.0 & 0.000 & 0.000 & -9.4 & -4.6 \\
\hline February & 0.579 & 0.668 & -6.0 & -5.4 & 0.579 & 0.740 & -5.9 & -5.5 \\
\hline March & 0.075 & 0.023 & -3.9 & -1.9 & 0.015 & 0.008 & -5.0 & -2.7 \\
\hline April & 0.063 & 0.054 & 0.7 & 2.2 & 0.003 & 0.002 & -1.1 & 1.2 \\
\hline May & 0.684 & 0.878 & 7.5 & 7.4 & 0.165 & 0.110 & 5.4 & 6.5 \\
\hline June & 0.631 & 0.546 & 10.3 & 9.9 & 0.393 & 0.405 & 8.7 & 9.2 \\
\hline July & 0.739 & 0.723 & 13.3 & 13.5 & 0.015 & 0.012 & 12.0 & 13.4 \\
\hline August & 0.631 & 0.771 & 13.1 & 13.3 & 0.123 & 0.070 & 12.2 & 13.4 \\
\hline September & 0.912 & 0.986 & 8.9 & 8.9 & 0.853 & 0.809 & 8.5 & 8.8 \\
\hline October & 0.218 & 0.230 & 3.0 & 3.7 & 0.105 & 0.157 & 2.2 & 3.1 \\
\hline November & 0.105 & 0.081 & -4.2 & -2.6 & 0.029 & 0.032 & -4.3 & -2.5 \\
\hline December & 1.000 & 0.870 & -8.4 & -8.2 & 0.912 & 0.980 & -7.6 & -7.6 \\
\hline
\end{tabular}


Table 7: Changes daily minimum temperature in annual, seasonal and monthly periods [Scheme S1]

\begin{tabular}{|l|r|r|r|r|r|r|r|r|}
\hline \multirow{2}{*}{ Seasons } & \multicolumn{5}{|c|}{ Athabasca } & \multicolumn{4}{|c|}{ Peyto } \\
\cline { 2 - 10 } & $\begin{array}{r}\text { p-value } \\
\text { Wilcox test }\end{array}$ & $\begin{array}{c}\text { p-value } \\
\text { t-test }\end{array}$ & $\begin{array}{c}\text { Mean 1 } \\
\left({ }^{\circ} \mathrm{C}\right)\end{array}$ & $\begin{array}{c}\text { Mean 2 } \\
\left({ }^{\circ} \mathrm{C}\right)\end{array}$ & $\begin{array}{c}\text { p-value } \\
\text { Wilcox test }\end{array}$ & $\begin{array}{c}\text { p-value } \\
\text { t-test }\end{array}$ & $\begin{array}{c}\text { Mean 1 } \\
\left({ }^{\circ} \mathrm{C}\right)\end{array}$ & $\begin{array}{c}\text { Mean } 2 \\
\left({ }^{\circ} \mathrm{C}\right)\end{array}$ \\
\hline Annual & 0.190 & 0.081 & -4.5 & -4.0 & 0.000 & 0.001 & -4.9 & -3.8 \\
\hline Winter & 0.971 & 0.671 & -12.3 & -12 & 0.853 & 0.673 & -11.2 & -10.9 \\
\hline Spring & 0.089 & 0.077 & -5.7 & -4.9 & 0.001 & 0.001 & -7.0 & -5.5 \\
\hline Summer & 0.043 & 0.023 & 4.5 & 5.2 & 0.000 & 0.000 & 3.7 & 5.0 \\
\hline Fall & 0.247 & 0.384 & -1.1 & -0.7 & 0.009 & 0.008 & -2.0 & -0.6 \\
\hline January & 0.007 & 0.012 & -15.0 & -11.4 & 0.001 & 0.003 & -13.3 & -9.8 \\
\hline February & 0.796 & 0.517 & -12.1 & -13.1 & 0.739 & 0.382 & -11.5 & -12.8 \\
\hline March & 0.684 & 0.490 & -9.8 & -9.2 & 0.089 & 0.067 & -10.8 & -9.3 \\
\hline April & 0.029 & 0.018 & -6.9 & -5.3 & 0.015 & 0.008 & -7.9 & -6.2 \\
\hline May & 1.000 & 0.699 & -0.5 & -0.3 & 0.004 & 0.004 & -2.4 & -1.0 \\
\hline June & 0.853 & 0.734 & 2.9 & 3.1 & 0.739 & 0.516 & 1.9 & 2.2 \\
\hline July & 0.043 & 0.023 & 5.4 & 6.4 & 0.000 & 0.000 & 4.3 & 6.2 \\
\hline August & 0.019 & 0.020 & 5.1 & 6.1 & 0.000 & 0.000 & 4.8 & 6.6 \\
\hline September & 0.280 & 0.169 & 0.7 & 1.6 & 0.190 & 0.182 & 0.8 & 1.6 \\
\hline October & 0.853 & 0.937 & -2.9 & -2.9 & 0.004 & 0.004 & -4.7 & -2.8 \\
\hline November & 0.631 & 0.807 & -9.2 & -9.4 & 0.739 & 0.985 & -8.5 & -8.5 \\
\hline December & 0.280 & 0.393 & -12.7 & -13.9 & 0.190 & 0.251 & -11.4 & -12.7 \\
\hline
\end{tabular}


Table 8: Changes daily mean temperature in annual, seasonal and monthly periods [Scheme S1]

\begin{tabular}{|l|r|r|r|r|r|r|r|r|}
\hline \multirow{2}{*}{ Seasons } & \multicolumn{4}{|c|}{ Athabasca } & \multicolumn{4}{|c|}{ Peyto } \\
\cline { 2 - 10 } & $\begin{array}{r}\text { p-value } \\
\text { Wilcox test }\end{array}$ & $\begin{array}{c}\text { p-value } \\
\text { t-test }\end{array}$ & $\begin{array}{c}\text { Mean 1 } \\
\left({ }^{\circ} \mathrm{C}\right)\end{array}$ & $\begin{array}{c}\text { Mean 2 } \\
\left({ }^{\circ} \mathrm{C}\right)\end{array}$ & $\begin{array}{c}\text { p-value } \\
\text { Wilcox test }\end{array}$ & $\begin{array}{c}\text { p-value } \\
\text { t-test }\end{array}$ & $\begin{array}{c}\text { Mean 1 } \\
\left({ }^{\circ} \mathrm{C}\right)\end{array}$ & $\begin{array}{c}\text { Mean } 2 \\
\left({ }^{\circ} \mathrm{C}\right)\end{array}$ \\
\hline Annual & 0.105 & 0.089 & -1.1 & -0.6 & 0.001 & 0.001 & -1.6 & -0.6 \\
\hline Winter & 0.481 & 0.336 & -9.7 & -9 & 0.529 & 0.342 & -8.9 & -8.4 \\
\hline Spring & 0.165 & 0.119 & -2 & -1.2 & 0.003 & 0.003 & -3.4 & -2 \\
\hline Summer & 0.393 & 0.392 & 8.7 & 9 & 0.003 & 0.002 & 7.6 & 8.7 \\
\hline Fall & 0.529 & 0.799 & 2.4 & 2.6 & 0.28 & 0.23 & 1.7 & 2.4 \\
\hline January & 0.004 & 0.006 & -12.5 & -8.6 & 0.000 & 0.001 & -11.3 & -7.6 \\
\hline February & 0.912 & 0.704 & -9.1 & -9.7 & 0.796 & 0.537 & -8.7 & -9.6 \\
\hline March & 0.353 & 0.234 & -6.8 & -5.8 & 0.075 & 0.058 & -7.9 & -6.3 \\
\hline April & 0.063 & 0.054 & -2.9 & -1.6 & 0.007 & 0.007 & -4.3 & -2.6 \\
\hline May & 0.579 & 0.943 & 3.8 & 3.8 & 0.105 & 0.044 & 1.8 & 3.0 \\
\hline June & 0.912 & 0.754 & 7.0 & 6.8 & 0.436 & 0.507 & 5.7 & 6.0 \\
\hline July & 0.190 & 0.214 & 9.7 & 10.3 & 0.002 & 0.001 & 8.4 & 10.1 \\
\hline August & 0.631 & 0.373 & 9.3 & 9.8 & 0.019 & 0.010 & 8.6 & 10.1 \\
\hline September & 0.739 & 0.727 & 4.8 & 5.1 & 0.631 & 0.727 & 4.7 & 5.0 \\
\hline October & 0.853 & 0.991 & 0.1 & 0.1 & 0.052 & 0.089 & -1.2 & -0.2 \\
\hline November & 0.853 & 0.870 & -6.5 & -6.4 & 0.971 & 0.632 & -6.2 & -5.8 \\
\hline December & 0.436 & 0.499 & -10.4 & -11.2 & 0.247 & 0.285 & -9.4 & -10.5 \\
\hline
\end{tabular}


Table 9: Results of Student's t-test for changes in annual mean values of water fluxes. Red numbers are significant at $95 \%$ confidence level. The comparisons were made as per the schemes defined in Table 3 .

\begin{tabular}{|c|c|c|c|c|c|c|c|}
\hline \multirow[b]{2}{*}{ Schemes } & \multirow[b]{2}{*}{ Fluxes } & \multicolumn{3}{|c|}{ Athabasca } & \multicolumn{3}{|c|}{ Peyto } \\
\hline & & p-value & $\begin{array}{c}\text { Mean } 1 \\
(\mathbf{m m})\end{array}$ & $\begin{array}{c}\text { Mean } 2 \\
(\mathrm{~mm})\end{array}$ & p-value & $\begin{array}{c}\text { Mean } 1 \\
(\mathbf{m m})\end{array}$ & $\begin{array}{c}\text { Mean } 2 \\
(\mathrm{~mm})\end{array}$ \\
\hline \multirow{6}{*}{ S1 } & Snow & 0.443 & 911 & 866 & 0.121 & 1135 & 919 \\
\hline & Rain & 0.001 & 175 & 262 & 0.304 & 310 & 362 \\
\hline & Snowmelt & 0.223 & 687 & 723 & 0.309 & 1105 & 974 \\
\hline & Firnmelt & 0.652 & 275 & 307 & 0.806 & 163 & 146 \\
\hline & Icemelt & 0.537 & 532 & 501 & 0.000 & 265 & 667 \\
\hline & Runoff & 0.578 & 1320 & 1365 & 0.005 & 1581 & 1888 \\
\hline \multirow{6}{*}{ S2 } & Snow & 0.892 & 911 & 901 & 0.591 & 1135 & 1060 \\
\hline & Rain & 0.983 & 175 & 175 & 0.923 & 310 & 313 \\
\hline & Snowmelt & 0.432 & 687 & 661 & 0.683 & 1105 & 1056 \\
\hline & Firnmelt & 0.930 & 275 & 267 & 0.095 & 163 & 39 \\
\hline & Icemelt & 0.245 & 532 & 470 & 0.225 & 265 & 364 \\
\hline & Runoff & 0.279 & 1320 & 1236 & 0.499 & 1581 & 1524 \\
\hline \multirow{6}{*}{ S3 } & Snow & 0.546 & 911 & 876 & 0.292 & 1135 & 986 \\
\hline & Rain & 0.001 & 175 & 262 & 0.326 & 310 & 360 \\
\hline & Snowmelt & 0.827 & 687 & 669 & 0.613 & 1105 & 1041 \\
\hline & Firnmelt & 0.587 & 275 & 314 & 0.015 & 163 & 414 \\
\hline & Icemelt & 0.460 & 532 & 571 & 0.003 & 265 & 537 \\
\hline & Runoff & 0.125 & 1320 & 1452 & 0.000 & 1581 & 2069 \\
\hline \multirow{6}{*}{ S4 } & Snow & 0.545 & 901 & 866 & 0.287 & 1060 & 919 \\
\hline & Rain & 0.001 & 175 & 262 & 0.340 & 313 & 362 \\
\hline & Snowmelt & 0.035 & 661 & 723 & 0.527 & 1056 & 974 \\
\hline & Firnmelt & 0.581 & 267 & 307 & 0.008 & 39 & 146 \\
\hline & Icemelt & 0.454 & 470 & 501 & 0.006 & 364 & 667 \\
\hline & Runoff & 0.101 & 1236 & 1365 & 0.001 & 1524 & 1888 \\
\hline \multirow{6}{*}{ S5 } & Snow & 0.785 & 876 & 866 & 0.606 & 986 & 919 \\
\hline & Rain & 0.986 & 262 & 262 & 0.974 & 360 & 362 \\
\hline & Snowmelt & 0.504 & 669 & 723 & 0.621 & 1041 & 974 \\
\hline & Firnmelt & 0.908 & 314 & 307 & 0.003 & 414 & 146 \\
\hline & Icemelt & 0.111 & 571 & 501 & 0.192 & 537 & 667 \\
\hline & Runoff & 0.295 & 1452 & 1365 & 0.124 & 2069 & 1888 \\
\hline
\end{tabular}


Table 10: Results of paired Student's t-test and Wilcox test for changes in monthly values of water fluxes. Red numbers are significant at $95 \%$ confidence level. The comparisons were made as per the schemes defined in Table 3 .

\begin{tabular}{|c|c|c|c|c|c|}
\hline \multirow[b]{2}{*}{ Schemes } & \multirow[b]{2}{*}{ Fluxes } & \multicolumn{2}{|c|}{ Athabasca } & \multicolumn{2}{|c|}{ Peyto } \\
\hline & & $\begin{array}{c}\text { p-value } \\
\text { t-test }\end{array}$ & $\begin{array}{c}\text { p-value } \\
\text { Wilcox test }\end{array}$ & $\begin{array}{c}\text { p-value } \\
\text { t-test }\end{array}$ & $\begin{array}{c}\text { p-value } \\
\text { Wilcox test }\end{array}$ \\
\hline \multirow{6}{*}{ S1 } & Snow & 0.424 & 0.986 & 0.028 & 0.018 \\
\hline & Rain & 0.000 & 0.000 & 0.141 & 0.000 \\
\hline & Snowmelt & 0.525 & 0.109 & 0.303 & 0.922 \\
\hline & Firnmelt & 0.540 & 0.181 & 0.741 & 0.552 \\
\hline & Icemelt & 0.437 & 0.859 & 0.000 & 0.000 \\
\hline & Runoff & 0.500 & 0.059 & 0.000 & 0.000 \\
\hline \multirow{6}{*}{ S2 } & Snow & 0.000 & 0.000 & 0.000 & 0.000 \\
\hline & Rain & 0.003 & 0.000 & 0.100 & 0.000 \\
\hline & Snowmelt & 0.000 & 0.000 & 0.028 & 0.262 \\
\hline & Firnmelt & 0.029 & 0.027 & 0.001 & 0.000 \\
\hline & Icemelt & 0.000 & 0.000 & 0.000 & 0.000 \\
\hline & Runoff & 0.000 & 0.000 & 0.023 & 0.057 \\
\hline \multirow{6}{*}{$\mathbf{S 3}$} & Snow & 0.538 & 0.839 & 0.138 & 0.113 \\
\hline & Rain & 0.000 & 0.000 & 0.162 & 0.001 \\
\hline & Snowmelt & 0.312 & 0.097 & 0.604 & 0.897 \\
\hline & Firnmelt & 0.460 & 0.125 & 0.003 & 0.002 \\
\hline & Icemelt & 0.336 & 0.072 & 0.000 & 0.000 \\
\hline & Runoff & 0.061 & 0.003 & 0.000 & 0.000 \\
\hline \multirow{6}{*}{ S4 } & Snow & 0.531 & 0.851 & 0.135 & 0.113 \\
\hline & Rain & 0.000 & 0.000 & 0.170 & 0.001 \\
\hline & Snowmelt & 0.265 & 0.013 & 0.496 & 0.613 \\
\hline & Firnmelt & 0.453 & 0.160 & 0.002 & 0.000 \\
\hline & Icemelt & 0.346 & 0.078 & 0.000 & 0.000 \\
\hline & Runoff & 0.048 & 0.004 & 0.000 & 0.000 \\
\hline \multirow{6}{*}{ S5 } & Snow & 0.000 & 0.000 & 0.000 & 0.000 \\
\hline & Rain & 0.234 & 0.000 & 0.511 & 0.000 \\
\hline & Snowmelt & 0.000 & 0.003 & 0.006 & 0.288 \\
\hline & Firnmelt & 0.035 & 0.062 & 0.000 & 0.000 \\
\hline & Icemelt & 0.000 & 0.000 & 0.000 & 0.000 \\
\hline & Runoff & 0.000 & 0.000 & 0.000 & 0.018 \\
\hline
\end{tabular}


Table 11: Results of Student's t-test and Wilcox test for changes in glacier mass balances. Red numbers are significant at $95 \%$ confidence level. The comparisons were made as per the schemes defined in Table 3.

\begin{tabular}{|c|c|c|c|c|c|c|c|c|c|}
\hline \multirow[b]{2}{*}{ Schemes } & \multirow[b]{2}{*}{$\begin{array}{c}\text { Mass } \\
\text { Balance }\end{array}$} & \multicolumn{4}{|c|}{ Athabasca } & \multicolumn{4}{|c|}{ Peyto } \\
\hline & & $\begin{array}{c}\text { p-value } \\
\text { Wilcox } \\
\text { test }\end{array}$ & $\begin{array}{c}\text { p- } \\
\text { value } \\
\text { t-test }\end{array}$ & $\begin{array}{c}\text { Mean } 1 \\
(\mathrm{~mm})\end{array}$ & $\begin{array}{c}\text { Mean } 2 \\
(\mathbf{m m})\end{array}$ & $\begin{array}{c}\text { p-value } \\
\text { Wilcox } \\
\text { test }\end{array}$ & $\begin{array}{c}p- \\
\text { value } \\
\text { t-test }\end{array}$ & $\begin{array}{c}\text { Mean } 1 \\
(\mathrm{~mm})\end{array}$ & $\begin{array}{c}\text { Mean } 2 \\
(\mathrm{~mm})\end{array}$ \\
\hline \multirow{3}{*}{ S1 } & Winter & 0.029 & 0.019 & 474 & 417 & 0.007 & 0.009 & 586 & 324 \\
\hline & Summer & 0.796 & 0.740 & -1176 & -1133 & 0.123 & 0.149 & -857 & -1056 \\
\hline & Annual & 0.579 & 0.910 & -701 & -716 & 0.029 & 0.019 & -271 & -733 \\
\hline \multirow{3}{*}{ S2 } & Winter & 0.280 & 0.233 & 474 & 447 & 0.043 & 0.059 & 586 & 401 \\
\hline & Summer & 0.247 & 0.522 & -1176 & -1083 & 0.123 & 0.249 & -857 & -709 \\
\hline & Annual & 0.315 & 0.663 & -701 & -636 & 0.739 & 0.830 & -271 & -308 \\
\hline \multirow{3}{*}{ S3 } & Winter & 0.353 & 0.219 & 474 & 444 & 0.315 & 0.278 & 586 & 474 \\
\hline & Summer & 0.481 & 0.686 & -1176 & -1229 & 0.011 & 0.010 & -857 & -1306 \\
\hline & Annual & 0.529 & 0.534 & -701 & -785 & 0.023 & 0.016 & -271 & -832 \\
\hline \multirow{3}{*}{ S4 } & Winter & 0.247 & 0.180 & 447 & 417 & 0.315 & 0.266 & 401 & 324 \\
\hline & Summer & 0.481 & 0.683 & -1083 & -1133 & 0.007 & 0.008 & -709 & -1056 \\
\hline & Annual & 0.529 & 0.519 & -636 & -716 & 0.023 & 0.014 & -308 & -733 \\
\hline \multirow{3}{*}{ S5 } & Winter & 0.218 & 0.245 & 444 & 417 & 0.089 & 0.075 & 474 & 324 \\
\hline & Summer & 0.218 & 0.374 & -1229 & -1133 & 0.105 & 0.114 & -1306 & -1056 \\
\hline & Annual & 0.436 & 0.506 & -785 & -716 & 0.481 & 0.625 & -832 & -733 \\
\hline
\end{tabular}

